\title{
Mutational analysis of the GAP-related domain of the neurofibromatosis type 1 gene in Brazilian NF1 patients
}

\author{
Alessandra B. Trovó ${ }^{1}$, Eny M. Goloni-Bertollo ${ }^{2}$, Ulises M. Mancini ${ }^{1}$, Paula Rahal ${ }^{1}$, \\ Walter F. de Azevedo Jr. ${ }^{3}$ and Eloiza H. Tajara ${ }^{1}$ \\ ${ }^{1}$ Universidade Estadual Paulista, Instituto de Biociências, Letras e Ciências Exatas, \\ Departamento de Biologia, São José do Rio Preto, SP, Brazil. \\ ${ }^{2}$ Faculdade de Medicina de São José do Rio Preto, São José do Rio Preto, SP, Brazil. \\ ${ }^{3}$ Universidade Estadual Paulista, Instituto de Biociências, Letras e Ciências Exatas, \\ Departamento de Física, São José do Rio Preto, SP, Brazil.
}

\begin{abstract}
Neurofibromatosis type 1 (NF1) is a common autosomal dominant disorder caused by mutations in the NF1 gene. In the present study, a total of 55 unrelated NF1 patients were screened for mutations in the GAP-related domain/GRD (exons 20-27a) by single-strand conformation polymorphism (SSCP). Four different mutations were identified and, taken together, they comprise one nonsense substitution (Q1189X), one deletion (3525-3526delAA), one missense substitution $(\mathrm{E} 1356 \mathrm{G})$ and one mutation in the splice acceptor site (c.4111-1G>A). One novel polymorphism (c.4514+11C>G) and other three putative polymorphisms were also found (c.3315-27G>A, V1146I and V1317A). Genotype-phenotype correlations were investigated, but no particular association was detected.
\end{abstract}

Key words: gene NF1, GRD, neurofibromatosis type 1, mutations, polymorphisms.

Received: July 31, 2003; Accepted: March 2, 2004.

\section{Introduction}

Neurofibromatosis type 1 is one of the most common autosomal dominant disorders, affecting approximately 1:3,000 individuals. The main characteristics of the disease comprise multiple neurofibromas, cafe-au-lait skin spots, Lisch nodules and freckling, but, in a minority of patients, other features, such as scoliosis, macrocephaly, short stature, malignancies, and learning disabilities, are also found (Huson and Hughes, 1994).

The NF1 gene, mapped to 17q11.2 (Barker et al., 1987), contains 60 exons and has one of the highest mutation rates described for human genes (Huson and Hughes, 1994). It is transcribed to an mRNA that encodes a protein, neurofibromin. A central region of this protein (exons 20-27a) shows functional and structural homology to the mammalian GTPase-activating protein (GAP). The GAPrelated domain (GRD) has been shown to down-regulate p $21^{\text {ras }}$ by accelerating the rate of GTP hydrolysis and inhibiting Ras-mediated signal transduction (Martin et al., 1990).

Send correspondence to Eloiza Helena Tajara. Universidade Estadual Paulista Instituto de Biociências, Letras e Ciências Exatas, Departamento de Biologia, São José do Rio Preto, SP, Brazil. E-Mail: tajara@bio.ibilce.unesp.br.
Ten years after the cloning of the $N F 1$ gene, mutation analysis and diagnostic testing remain a challenge, mainly due to the large size of the gene, the presence of several pseudogenes and the lack of mutational hotspots. Despite these difficulties, more than 400 different NF1 mutations have been reported (http://www.hgmd.org; http://www. clam.com/nf/nflgene). Different methodologies have been used to screen mutations in the NF1 gene. Denaturing high-performance liquid chromatography (DHPLC) was used by Han et al. (2001) and De Luca et al. (2003), and the mutation detection rates were $97 \%$ and $72.5 \%$, respectively. Heteroduplex, FISH, Southern blot, PTT, TGGE and genomic sequencing were also used by Fahsold et al. (2000) and Messiaen et al. (2000), and up to 95\% of mutations were identified. Mutations in the GAP-related domain in lung cancer samples have been screened by Furukawa $e t$ al. (2003) using SSCP and sequencing, with a mutation and polymorphism detection rate of $8 \%$.

No genotype-phenotype correlation has been detected, except for microdeletions and deletions encompassing the entire gene, or perhaps contiguous genes also, in patients with facial anomalies, great number of neurofibromas and severe developmental delay (Wu et al., 1995; Leppig et al., 1996; Lopez-Correa et al., 2001). 
Learning disabilities have also been observed in patients with different inactivating mutations and even in NF1 mutant flies and mice (Guo et al., 2000; Costa et al., 2001; Costa and Silva, 2003). Relatively few learning disability data based on IQ tests are reported in molecular studies on neurofibromatosis.

In the present study, we analyzed 55 patients with NF1 for mutations in the GAP-related domain (GRD) of the NF1 gene.

\section{Materials and Methods}

Fifty-five unrelated Brazilian NF1 patients were examined within our multidisciplinary NF1 Program. Thirtythree were familial cases and twenty-two were sporadic. Clinical details were fully documented. Cognitive functions were evaluated using either Wechsler's Intelligence Scale for Children (WISC) or Wechsler's Adult Intelligence Scale (WAIS) tests. All patients gave their informed consent prior to inclusion in the study.

DNA was extracted from peripheral blood leukocytes and amplified by PCR, using the intron-based primers flanking NF1 exons 20-27a (GRD). For exons 20, 22, 23.1, 23.2, 23a, 24 and 26, the primers used for amplification were those described by Li et al. (1995) and Van Meyel et al. (1994). For exons 21, 25 and 27a, PCR primers were developed using Primer3 software (http://www.genome.wi. mit.edu/cgi-bin/primer/primer3_www.cgi). The GenBank accession numbers of the NF1 wild-type sequence were U17683-U17689 (exons 20-27a).

Amplified fragments were then subjected to SSCP analysis. All aberrant SSCP mobility patterns were verified on a second PCR-SSCP analysis, and the DNA samples were automatically sequenced in an ABI 377 PRISM DNA Sequencer (Applied Biosystems). The mutations were also investigated on 100 unrelated alleles, and polymorphisms in 200 control samples.
For molecular modeling we used homology modeling implemented in the program MODELLER (Sali and Blundell, 1993). The atomic coordinates of the GAPrelated domain - NF1GRD (NF1-333; residues 1198-1530; PDB access code: $1 \mathrm{NF} 1)$ were used as template. To generate the complex NF1(E1356G)-Ras, the atomic coordinates of p120GAP (GAP-334; residues 1218-1510; PDB access code: 1WQ1) were used as template (Scheffzek et al., 1998).

\section{Results and Discussion}

In the 55 unrelated patients screened, four different mutations were identified, of which three are novel: one missense and one nonsense substitutions, and one mutation in the splice acceptor site. Four polymorphisms were also found (Table 1).

The missense mutation (E1356G) of patient 26 (exon 23.2) changed a negatively charged polar for a non-polar amino acid in the peptide. Such a substitution may alter the protein structure and is, thus, likely to be disease-causative. From the information available on neurofibromin sequences of mouse and rat (Genbank L10370 and D45201), this amino acid substitution occurred in a highly conserved position of GRD (identical in human, mouse and rat) and may be essential for GAP function. However, an analysis of the molecular model of the complex NF1(E1356G)-Ras strongly indicated that this mutation has no influence on the interaction between NF1 and Ras, since it is far from the protein-protein interface of the complex (Figure 1).

While the cause of disease in patients with missense mutations is unclear, the significance of stop codons is obvious. In the present study, we identified one nonsense mutation (Q1189X). This mutation (case 28) was identified in exon 21 and is predicted to lead to a severely truncated protein, with only 1,188 amino acids instead of the normal 2,818 .

Table 1 - NF1 mutations and polymorphisms in nine unrelated patients with neurofibromatosis type 1.

\begin{tabular}{|c|c|c|c|c|c|c|}
\hline \multirow[t]{2}{*}{ Location } & \multirow[t]{2}{*}{ Patient } & \multirow[t]{2}{*}{ Age (years) } & \multirow{2}{*}{$\begin{array}{c}\text { Sporadic/ } \\
\text { Familial }\end{array}$} & \multicolumn{3}{|c|}{ Mutation } \\
\hline & & & & cDNA & Protein & Type \\
\hline Intron $19 \mathrm{~b}$ & 34 & 21 & $\mathrm{~S}$ & c. $3315-27 \mathrm{G}>\mathrm{A}$ & & polymorphism \\
\hline Exon 20 & 24 & 27 & S & $3436 \mathrm{G}>\mathrm{A}$ & V1146I & polymorphism \\
\hline Exon 21 & 28 & 46 & S & $3565 \mathrm{C}>\mathrm{T}$ & Q1189X & nonsense \\
\hline Exon 21 & 32 & 52 & $\mathrm{~S}$ & 3525-3526delAA & PTC 1193 & deletion \\
\hline Exon 23.1 & 8 & 37 & $\mathrm{~F}$ & $3950 \mathrm{~T}>\mathrm{C}$ & V1317A & polymorphism \\
\hline Exon 23.2 & 26 & 12 & S & $4067 \mathrm{~A}>\mathrm{G}$ & E1356G & missense \\
\hline Intron 23.2 & 18 & 39 & F & c. $4111-1 \mathrm{G}>\mathrm{A}$ & $?$ & splice site \\
\hline Intron 26 & 16 & 52 & S & c. $4514+11 \mathrm{C}>\mathrm{G}$ & & polymorphism \\
\hline Intron 26 & 36 & 37 & $\mathrm{~S}$ & c. $4514+11 \mathrm{C}>\mathrm{G}$ & & polymorphism \\
\hline
\end{tabular}

$\mathrm{PTC}=$ premature termination codon

$\mathrm{V}=$ valine $\mathrm{I}=$ isoleucine, $\mathrm{Q}=$ glutamine, $\mathrm{X}=$ stop codon, $\mathrm{A}=$ alanine, $\mathrm{E}=$ glutamic acid, $\mathrm{G}=$ glycine. 


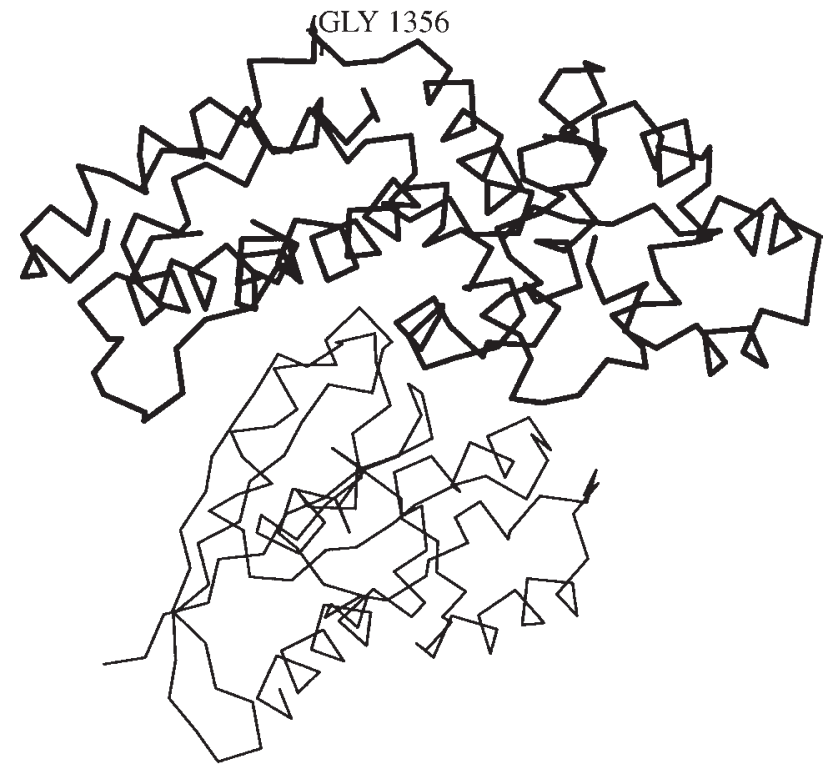

Figure 1 - C $\alpha$-backbone for the complex NF1(E1356G)-Ras, showing the G1356 position in the structure. NF1 is drawn with thick lines and Ras with thin lines.
The deletion of two adenines, at nucleotide 3,525 in exon 21 (patient 32), caused a shift in the reading frame, leading to the creation of a premature stop codon at nucleotide 3,580 . This mutation may result in the generation of a shortened, non-functional protein of 1,192 amino acids. Recently, the same mutation was reported by Fahsold et al. (2000) and Serra et al. (2001), but, as in the case of the nonsense mutation, the clinical features of these patients are not available for comparison.

One mutation (case 18) was found in a splice site (c.4111-1G>A) and probably destroyed the acceptor consensus sequence of intron 23.2. Family members of this patient were available for analysis, and the presence of the mutation segregated with the disease. Upadhyaya et al. (1997) and Fahsold et al. (2000) found different splicing mutations at the donor site of the same intron.

A novel polymorphism $(\mathrm{c} .4514+11 \mathrm{C}>\mathrm{G})$ was detected in intron 26 (patients 16 and 36). This polymorphism was also observed in 3 out of 200 control samples. Other three putative polymorphisms were found in exons 20 (V1146I) and 23.1 (V1317A) and in intron 19b

Table 2 - Clinical features of Brazilian NF1 patients with a predicted prematurely truncated neurofibromin protein (cases 28, 32 and 18) and a missense mutation (case 26) in the NF1 gene (EEG = electroencephalogram; $E C G=$ electrocardiogram).

\begin{tabular}{|c|c|c|c|c|}
\hline & \multicolumn{3}{|c|}{ Predicted truncated protein } & \multirow{2}{*}{$\begin{array}{c}\text { Missense mutation } \\
\text { Case } 26\end{array}$} \\
\hline & Case 28 & Case 32 & Case 18 & \\
\hline $\begin{array}{l}\text { Age at diagnosis } \\
\text { (years)/Sex }\end{array}$ & $46 / \mathrm{F}$ & $52 / \mathrm{M}$ & $39 / \mathrm{F}$ & $12 / \mathrm{M}$ \\
\hline Cafe-au-lait spots & + & + & +++ & + \\
\hline Freckling & +++ & + & +++ & ++ \\
\hline Neurofibromas & ++ & +++ & ++ & + \\
\hline Plexiform neurofibromas & - & - & - & - \\
\hline Lisch nodules & NA & + & + & +++ \\
\hline Macrocephaly & - & - & - & + \\
\hline Short stature & + & - & - & - \\
\hline Mental retardation* & mild & - & mild & borderline \\
\hline Abnormal EEG & NA & - & + & - \\
\hline Abnormal ECG & + & + & + & - \\
\hline $\begin{array}{l}\text { Ophthalmological } \\
\text { complications }\end{array}$ & NA & $\begin{array}{l}\text { eyelid neurofibroma, } \\
\text { retina glioma, pterygium }\end{array}$ & $\begin{array}{c}\text { eyelid and conjuntiva } \\
\text { neurofibroma, ptosis, } \\
\text { pterygium }\end{array}$ & - \\
\hline Skeletal anomalies & cystic lesions & $\begin{array}{l}\text { scoliosis, lumbosacral } \\
\text { transition vertebra }\end{array}$ & $\begin{array}{l}\text { scoliosis, kyphosis, } \\
\text { scalloping }\end{array}$ & $\begin{array}{c}\text { pectus } \\
\text { excavatum, osteolytic } \\
\text { lesions, cortical fibroma, } \\
\text { cystic lesions }\end{array}$ \\
\hline Other & - & $\begin{array}{l}\text { hemorrhoids, intestinal } \\
\text { constipation }\end{array}$ & headache, hypertension & $\begin{array}{l}\text { headache, respiratory } \\
\text { problems, dyslexia, spatial } \\
\text { orientation problems }\end{array}$ \\
\hline
\end{tabular}

$\mathrm{M}=$ male, $\mathrm{F}=$ female $;+=$ presence of clinical sign, - = absence of clinical sign, $\mathrm{NA}=$ not ascertained.

N. of plug signs indicates level of severity:

$+=\leq 50,++=51-150,+++=>150$ (café-au-lait spots and neurofibromas).

$+=\leq 4,++=5-8,+++=>8$ (freckling).

$+=\leq 3,++=4-6,+++=>6$ (Lisch nodules).

* based on IQ test (IQ = intelligence quotient): (IQ $\geq 85=$ normal; $70 \geq \mathrm{IQ}<85=$ borderline; $50 \geq \mathrm{IQ}<70=$ mild mental retardation). 
(c. $3315-27 \mathrm{G}>\mathrm{A}$ ) in patients 24,8 and 34 , respectively, but in none of the 200 control samples. Both V1146I and V1317A replace a non-polar R group by another non-polar $\mathrm{R}$ group and are substitutions often found as polymorphisms in other genes (Miller and Kumar, 2001). The latter polymorphism segregated with the disease in the patient's family and is therefore likely to be located on the same chromosome as the NF1 mutation. Molecular modeling might clarify if V1146I and V1317A affect the structure of the neurofibromin GAP-related domain. However, it is not possible to generate a molecular model for both, because the template NF1GRD (NF1-333; residues 1198-1304 and 1331-1551; PDB access code: 1NF1) has no atomic coordinates in these regions (Scheffzek et al., 1998).

This is the first report on mutational screening in a large number of Brazilian NF1 patients. As in previous studies, we were unable to correlate the presence or severity of clinical features and/or mental retardation with the site of the mutation (Table 2). This is not unexpected, given the wide range of clinical variability that has previously been reported, even in different members of the same family. As Messiaen et al. (2000) questioned: Do genotype-phenotype correlations in NF1 exist? It is possible that the clinical picture is dependent on many endogenous and exogenous, transitory or lasting, environmental factors. Therefore, in addition to more sensitive methods of mutation detection, studies on gene function are necessary to understand the pathogenesis of this disease. The greatest challenge for the next years will undoubtedly be to link the phenotypic features to the role of neurofibromin and related proteins in growth control and cell differentiation.

\section{Acknowledgments}

This work was supported by FAPESP (Fundação de Amparo à Pesquisa do Estado de São Paulo), CNPq (Conselho Nacional de Desenvolvimento Científico e Tecnológico) and CAPES (Coordenação de Aperfeiçoamento de Pessoal de Nível Superior). We are grateful to the NF1 patients for their willing participation in this study. We also thank Professor Solange Aranha for critically reading the English manuscript and Professor Ana Elizabete Silva for generously providing the control DNA samples.

\section{References}

Barker D, Wright E, Nguyen K, Cannon L, Fain P, Goldgar D, Bishop DT, Carey J, Baty B, Kivlin J, Willard H, Waye JS, Greig G, Leinwand L, Nakamura Y, O'Connel P, Leppert M, Lalouel JM, White R and Skolnick M (1987) Gene for von Recklinghausen neurofibromatosis is in the pericentromeric region of chromosome 17. Science 236:1100-1102.

Costa RM, Yang T, Huynh DP, Pulst SM, Viskochil DH, Silva AJ and Brannan CI (2001) Learning deficits, but normal devel- opment and tumor predisposition, in mice lacking exon 23a of $N f 1$. Nature Genet 27:399-405.

Costa RM and Silva AJ (2003). Mouse models of neurofibromatosis type I: bridging the GAP. Trends Mol Med 9:19-23.

De Luca A, Buccino A, Gianni D, Mangino M, Giustini S, Richetta A, Divona L, Calvieri S, Mingarelli R and Dallapiccola B (2003) NF1 gene analysis based on DHPLC. Hum Mutat 21:171-2.

Fahsold R, Hoffmeyer S, Mischung C, Gille C, Ehlers C, Kücükceylan N, Abdel-Nour M, Gewies A, Peters H, Kaufmann D, Buske A, Tinschert S and Nürnberg P (2000) Minor lesion mutational spectrum of the entire NF1 gene does not explain its high mutability but points to a functional domain upstream of the GAP-related domain. Am J Hum Genet 66:790-818.

Furukawa K, Yanai N, Fujita M and Harada Y (2003) Novel mutations of neurofibromatosis type 1 gene in small cell lung cancers. Surg Today 33:323-7.

Guo HF, Tong J, Hannan F, Luo L and Zhong Y (2000) A neurofibromatosis-1-regulated pathway is required for learning in Drosophila. Nature 403:895-898.

Han SS, Cooper DN and Upadhyaya MN (2001) Evaluation of denaturing high performance liquid chromatography (DHPLC) for the mutational analysis of the neurofibromatosis type 1 (NF1) gene. Hum Genet 109:487-97.

Huson SM and Hughes RAC (1994) The neurofibromatoses: A pathogenetic and clinical overview. Chapman and Hall Medical, London, pp 487.

Leppig KA, Viskochil D, Neil S, Rubenstein A, Johnson VP, Zhu XL, Brothman AR and Stephens K (1996) The detection of contiguous gene deletions at the neurofibromatosis 1 locus with fluorescence in situ hybridization. Cytogenet Cell Genet 72:95-98.

Li Y, O'Connell P, Breidenbach HH, Cawthon R, Stevens J, Xu G, Neil S, Robertson M, White R and Viskochil D (1995) Genomic organization of the neurofibromatosis 1 gene (NF1). Genomics 25:9-18.

Lopez-Correa C, Dorschner M, Brems H, Lazaro C, Clementi M, Upadhyaya M, Dooijes D, Moog U, Kehrer-Sawatzki H, Rutkowski JL, Fryns JP, Marynen P, Stephens K and Legius E (2001) Recombination hotspot in NF1 microdeletion patients. Hum Mol Genet 10:1387-92.

Martin GA, Viskochil D, Bollag G, McCabe PC, Crosier WJ, Haubruck H, Conroy L, Clark R, O'Connell P, Cawthon RM, Innis MA and McCormick F (1990) The GAP-related domain of the neurofibromatosis type 1 gene product interacts with ras p21. Cell 63:843-849.

Messiaen LM, Callens T, Mortier G, Beysen D, Vandenbroucke I, Van Roy N, Speleman F and Paepe AD (2000) Exhaustive mutation analysis of the NF1 gene allows identification of $95 \%$ of mutations and reveals a high frequency of unusual splicing defects. Hum Mutat 15:541-555.

Miller MP and Kumar S (2001) Understanding human disease mutations through the use of interspecific genetic variation. Hum Mol Genet 10:2319-2328.

Sali A and Blundell TL (1993) Comparative protein modelling by satisfaction of spatial restraints. J Mol Biol 234:779-815.

Scheffzek K, Ahmadian MR, Wiesmüller L, Kabsch W, Stege P, Schmitz F and Wittinghofer A (1998) Structural analysis of 
the GAP-related domain from neurofibromin and its implications. Embo J 17:4313-4327.

Serra E, Ars E, Ravella A, Sánchez A, Puig S, Rosenbaum T, Estivill X and Lázaro C (2001) Somatic NF1 mutational spectrum in benign neurofibromas: mRNA splice defects are common among point mutations. Hum Genet 108:416-429.

Upadhyaya M, Osborn MJ, Maynard J, Kim MR, Tamanoi F and Cooper DN (1997) Mutational and functional analysis of the neurofibromatosis type 1 (NF1) gene. Hum Genet 99:88-92.
Van Meyel DJ, Ramsay DA, Chambers AF, MacDonald DR and Cairncross JG (1994) Absence of hereditary mutations in Exons 5 through 9 of the p53 gene and Exon 24 of the neurofibromin gene in families with glioma. Ann Neurol 35:120-122.

Wu BL, Austin MA, Schneider GH, Boles RG and Korf BR (1995) Deletion of the entire NF1 gene detected by FISH: Four deletion patients associated with severe manifestations. Am J Med Genet 59:528-535.

Associate Editor: Emmanuel Dias Neto 